\title{
Det femte nordiske kriminalistmøde i Helsingfors
}

Det er nu fastlagt, at det femte nordiske kriminalistm $\phi$ de afholdes i Helsingfors i dagene den 10. til 12. juni 1962.

Et forberedende m $\phi$ de afholdtes i Helsingfors den 19. november 1960. Formanden i Finlands kriminalistforening, professor Bo Palmgren ledede m $\phi$ det. De $\phi$ vrige deltagere var fra Danmark formanden for Dansk Kriminalistforening, professor Stephan Hurwitz, fra Finland professor Brynolf Honkasalo, docent Inkeri Anttila, fil. mag. Kaarlo Helasvuo og vicehäradshövding Marga Ahlqvist, fra Norge formanden for Norsk kriminalistforening, riksadvokat Andreas Aulie, fra Sverige næstformanden i Sveriges kriminalistforening, professor Ivar Strahl. Island havde ikke kunnet lade sig repræsentere.

På grundlag af tidligere fremsendte forslag fra de nordiske kriminalistforeningers styrelser valgtes som plenaremner:

Første mødedag den 10. juni: Forholdsregler mod ungdomskriminaliteten set på baggrund af kriminalitetens udvikling $i$ de nordiske lande gennem de seneste år. - Referent: Finland. Korreferenter: Sverige (hoved-korreferent), Danmark, Island, Norge.

Tredie mфdedag den 12. juni: Forh $\phi r$ (afhфring) af mistrnkte (sigtede), tiltalte og vidner $i$ straffesager. - Referent: Norge. Korreferent: Finland.

Som sektionsemner valgtes:

Anden mødedag den 11. juni: 1) formiddag: Livstidsstraffen. —Referent: Danmark.—2) formiddag: Efterforskningen (undersökningen) af omfattende forbrydelser på det фkonomiske livs område. - Referent: Finland. - 3) eftermiddag: Tilsyn og anden forsorg (eftervård) efter kort frihedsstraf. - Referent: Sverige. - 4) eftermiddag: Forholdsregler mod den, som truer (hotar) med forbrydelse. -- Referent: Danmark.

De respektive styrelser skal vælge referenter og korreferenter.

Offentligg $\phi$ relse af det forberedende skriftlige grundlag for forhandlingsemnerne skal ske på samme måde som ved det foregående nordiske kriminalistm $\varnothing$ de i Oslo i 1957, d. v. s. gennem publicering i Nordisk Tidsskrift for Kriminalvidenskab i det f $\phi \mathbf{r}$ ste hefte af årgangen 1962. 